\title{
Konsep Fitrah Dalam Pendidikan Islam
}

\author{
Fathorrahman, M.Pd.I
}

Dosen STIT Aqidah Usymuni Tarate Pandian Sumenep

\begin{abstract}
Abstrak
Fitrah manusia adalah ketentuan mutlak yang diberikan dari Tuhan. Fitrah manusia berbeda dengan watak atau tabiat. Juga berbeda dengan naluri atau gharizah. Watak atau tabiat adalah sifat dasar. Misal, watak dasar dari bensin adalah mudah terbakar. Jadi watak adalah karakteristik yang terdiri dari pada bentuk dan materi. Inilah yang merupakan watak atau tabiat suatu benda. Sedangkan naluri atau gharizah adalah sifat dasar. Misalnya anak kuda begitu lahir langsung bisa berdiri. Semut, mekipun binatang yang kecil tapi mampu mengumpulkan makanan. Inilah yang disebut dengan naluri.
\end{abstract}

Kata Kunci: Fitrah Dan Pendidikan Islam

\section{Pendahuluan}

Secara etimologi asal kata fitrah ${ }^{1}$ dari bahasa arab yaitu Fitratun jamaknya Fitarun. Artinya perangai, tabiat, kejadian asli, agama, ciptaan. ${ }^{2}$ Fitrah juga terambil dari akar kata Al-Fathr yang berarti belahan. Dari makna ini lahir maknamakna lain, antara lain "pencipta" atau "kejadian". 3 Dalam kamus Bahasa Indonesia, kata Fitrah diartikan dengan sifat asli, bakat, pembawaan perasaan keagamaan (misalnya: agama yang tidak selaras dengan kemajuan pikiran yang sehat, bukanlah agama fitrah namanya). ${ }^{4}$ Dalam kamus Munjid kata fitrah diartikan dengan agama, sunnah, kejadian dan tabiat. ${ }^{5}$

Kata fitrah dalam al-Qur'an disebutkan sebanyak 20 kali dengan berbagai bentuknya. Dalam fi'il madli 9 kali, fitrah berarti menciptakan, menjadikan. Dalam fi'il mudlari' 2 kali, fitrah berarti pecah, terbalah. Dalam bentuk isim fa'il

\footnotetext{
${ }^{1}$ Muis Sad Iman, Pendidikan Partisipatif: Menimbang Konsep Fitrah dan progresivisme Joh Dewey,(Yogyakarta: Safiria Insania Press, 2004), 34-35) 215 .

${ }^{2}$ Hasan Langgulung, Pendidikan dan Peradaban Islam, (Jakarta: Pustaka Al Husna, 1985),

${ }^{3}$ M. Quraish Shihab, Wawasan Alqur'an,(Bandung: Mizan, 1996), 283.

${ }^{4}$ WJS Poerwodarminto, Kamus Umum Bahasa Indonesia (Jakarta: Balai Pustaka, 1952), 202.

${ }^{5}$ Luis Ma'luf, Al Munjid,(Beirut: tt), 619.
} 
6 kali, fitrah berarti yang menciptakan, yang menjadikan. Dalam bentuk isim maf'ul 1 kali, fitrah berarti pecah, terbelah. Dan dalam bentuk isim mashdar 2 kali, fitrah berarti tidak seimbang. ${ }^{7}$

Fitrah manusia berbeda dengan watak atau tabiat. Juga berbeda dengan naluri atau gharizah. Watak atau tabiat adalah sifat dasar. Misal, watak dasar dari bensin adalah mudah terbakar. Jadi watak adalah karakteristik yang terdiri dari pada bentuk dan materi. Inilah yang merupakan watak atau tabiat suatu benda. Sedangkan naluri atau gharizah adalah sifat dasar. Misalnya anak kuda begitu lahir langsung bisa berdiri. Semut, mekipun binatang yang kecil tapi mampu mengumpulkan makanan. Inilah yang disebut dengan naluri.

Dalam naluri tidak terdapat kesadaran yang penuh. Untuk binatang fitrah ini disebut dengan naluri. Fitrah sama dengan watak dan naluri. Namun istilah fitrah hanya untuk manusia. Fitrah manusia ini juga bukan diperoleh melalui usaha. Istilah fitrah lazimnya untuk manusia, naluri lazimnya untuk hewan, dan watak lazimnya untuk benda. ${ }^{8}$

\section{Fitrah Manusia}

Konsep fitrah ${ }^{9}$ manusia yang mengandung pengertian pola dasar kejadian manusia dapat dijelaskan dengan meninjau:

\section{Hakekat Wujud Manusia.}

Manusia mahluk Jasmani Ruhani yang paling mulia. Dari segi jasad atau fisik, manusia berasal dari tanah. Setelah berproses menjadi bentuk manusia dalam al-Qur'an disebut basyar (QS. Al Hijr: 28) yakni mahluk fisik biologis.

\footnotetext{
${ }^{7}$ Muis Sad Iman, Pendidikan Partisipatif: Menimbang Konsep Fitrah dan progrsivisme John Dewe, (Yogyakarta: Safiria Insania Press, 2004), 18.

${ }^{8}$ Idris Al Marbawi, Kamus Arab - Melayu, (Mesir:1350H), 96.

${ }^{9}$ Sesungguhnya pada manusia-akibat adanya perjanjian primordial- ada bibit kecucian dan kebaikan penciptaan asal yang suci (fitrah) yang berkecenderungan suci (hanif). Fitrah itu tidak akan berubah sepanjang masa, karena itu juga merupakan lokus bagi kearifan abadi (al-hikmah alkholidah, Sophia perennis). Akan tetapi sekalipun manusia dilahirkan dalam keadaan fitrah, tidak selamanya manusia memiliki sensitivitas fitrah diperlukan untuk menangkap kebenaran, dikarenakan timbunan dan tumpukan tebal puing-puing pengalaman social dan budaya lingkungannya. Dalam keadaan fitrah yang tumpul atau kehilangan sensitivitas itulah manusia menyimpang dari kesucian dan menempuh hidup yang aniaya atau zalim kepada diri sendiri. Nurkholish Madjid, Dialog Agama-AgamaDalam Perspektiv Universalisme al-Islam (Jakarta: Gramedia, 1998), 14.
} 
Sebagai mahluk biologis kejadiannya hamper sama dengan mahluk biologis lainnya terutama jenis binatang mamalia, yaitu dari Nutfah, 'alaqah kemudian mudghah (embrio) dan akhirnya terbentuklah janin, yang strukturnya secara gradual lebih sempurna dari bianatang (QS. At-Tin:4).

Setelah pembentukan fisik mendekati sempurna dalam bentuk janin, Allah meniupkan Ruh-Nya kepada manusia dan sejak itu dia benart-benar menjadi makhluk jasmani-ruhani yang mulia sehingga para malaikat pun diperintahkan oleh Allah agar tunduk kepada manusia (QS. Al Hijr: 29).

Bila dikaitkan dengan asal kejadian tadi, manusia mahluk yang suci ketika lahir. Ia tidak dibebani dosa oleh siapapun, termasuk dosa-dosa dari kedua orang tuanya. Sebagai rangkaian wujudnya yang suci di kala lahir, Tuhan senantiasa akan membimbingnya dengan agama yang sesuai dengan fitrah manusia. Manusia diciptakan dengan naluri beragama, yaitu agama Tauhid. Karena itu manusia yang tidak beragama tauhid merupakan penyimpangan atas fitrahnya.

2. Tujuan Penciptaan.

Tujuan Utama Penciptaan manusia ialah agar manusia beribadah kepada Allah, manusia dicipta untuk diperankan sebagai Wakil Tuhan di muka bumi dan manusia dicipta untuk saling mengenal, menghormati, dan tolong menolong.

3. Sumber Daya Insani.

Agar manusia dapat melaksanakan tugas dan tanggungjawabnya, Allah tidak membiarkan manusia hidup begitu saja tanpa bekal yang memadai. Allah dengan sifat rahman dan rahim-Nya memberikan potensi insani atau Sumber Daya Manusia (SDM) untuk dikembangkan dan ditinkatkan kwalitasnya. Esensi SDM yang membedakan dengan dengan potensi-potensi yang diberikan kepada mahkl;uk lainya dan memang sangat tinggi nilainya ialah: kebebasan dan hidayah Allah, yang sesungguhnya inhern dengan fitrah manusia. SDM agar terus berkembang dan maju manusia juga mendapatkan kapasitas belajar. Kapasitas belajar ini ada karena adanya kebebasan dan hidayah, terutama akal.

4. Citra Manusia Dalam Islam.

Berdasarkan uraian tentang fitrah manusia ditinjau dari hakekat wujudnya, tujuan penciptaannya dan sumber daya insaninya, tergambarlah secara jelas 
bagaimana citra manusia menurut pandangan Islam: pertama, Islam berwawasan optimistic, kedua, perjuangan manusia bukan sekedar trial and error, ketiga, manusia mahluk yang paling mampu bertanggung jawab.

\section{Fitrah dalam Tinjauan Al-Qur'an dan As-Sunnah}

Ayat-ayat al Qur'an yang menyebutkan kata fitrah terdapat dalam 17 surah. Diantara yang seringkali dibahas dalam mencari pengertian fitrah adalah QS. ArRum: “ Maka hadapkanlah wajahmu dengan lurus kepada agama Allah, (tetaplah atas) fitrah Allah yang telah menciptakan manusia menurut fitrah itu. Tidak ada perubahan pada fitrah Allah. Itulah agama yang lurus, tetapi kebanyakan manusia tidak mengetahui. (QS. Ar-Rum:30).

Sehubungan dengan kata fitrah yang tersebut dalam ayat ini ada sebuah hadits sohih yang diriwayatkan oleh Bukhori dan Muslim dari Abu Hurairah: "tidak ada satu anakpun yang dilahirkan kecuali dalam keadaan fitrah, maka kedua orang tuanyalah yang menyebabkannya menjadi Yahudi, Nasrani atau Majusi. (HR. Bukhori dan Muslim dari Abu Hurairah).

Pemaknaan terhadap istilah fitrah tersebut dalam beberapa kitab tafsir terdapat bebrapa makna yang beragam, di antaranya adalah:

1. Fitrah Berarti Agama, Kejadian.

Maksudnya, agama Islam ini bersesuaian dengan kejadian manusia. Sedang kejadiannya itu tidak berubah. Kalau sekiranya kita birakan manusia itu berpikir dengan pikirannya yang waras, niscaya ia akan sampai pada Islam. Tetapi karena manusia itu terpengaruh oleh adat istiadat dan pergaulannya, maka ia menjadi terjauh dari agama Islam. ${ }^{10}$

2. Fitrah Allah berarti Ciptaan Allah

Manusia diciptakan Allah mempunyai naluri beragama, yaitu agama Tauhid. Maka dari itu tidaklah wajar kalau manusia tidak beragama tauhi. Mereka tidak beragama tauhid itu hanyalah pengaruh lungkungan. Tegasnya manusia menurut fitrah beragama tauhid. ${ }^{11}$

\footnotetext{
10 Al-Quran dan Tafsirnya, (Yogyakarta: Dana Bhakti Wakaf, 1995), 571.

11 Al-Quran dan Terjemahnya, (Madinah Munawwaroh: 1411 H) 645.
} 
3. Fitrah Berarti Ciptaan, Kodrat Jiwa, Budi Nurani.

Maksudnya bahwa rasa keagamaan, rasa pengabdian kepada Tuhan yang Maha Esa itu, adalah serasi dengan budi nurani manusia. Adapun manusia yang bertuhankan selain Allah, adalah menyalahi kodrat kemanusiaannya sendiri. Itulah agama yang lurus tetapi manusia sering tidak mengetahui. ${ }^{12}$

4. Fitrah berarti mengakui keesaan Allah (Tauhid)

Manusia lahir membawa konsep tauhid atau ada kecenderungan mengesakan Tuhannya (Allah Swt), dan berusah terus untuk mencapai ketauhidan tersebut. $^{13}$

\section{Fitrah berarti potensi dasar Manusia}

Potensi dasar manusia ini sebgai alat untuk mengabdi dan ma'rifatullah. Penafsiran ini dikembangkan oleh filosof dan fuqaha. Para filosof yang beraliran empirisme memandang aktivitas fitrah sebagai tolak ukur pemaknaannya, demikian juga fuqaha memandang manusia merupakan cerminan dari jiwanya, sehingga hokum diterapkan menurut apa yang terlihat, bukan dari hakekat dibalik perbuatan tersebut. Seperti Q.S Yasin: 22, firman Allah ini menyatarakan lafadz a'budu dengan lafadz fataro yang berimplikasikan bahwa wujud fitrah manusia ditandai dengan ibadahnya kepada sang pencipta. ${ }^{14}$

\section{Strategi dan Pendekatan Pendidikan Islam}

Sebelum menjelaskan strategi dan pendekatan pendidikan Islam, lebih jelasnya penulis akan memaparkan pengertian pendidiakn Islam oleh beberapa cendekiawan Muslim.

M. Yusuf Al-Qardhawi memberikan pengertian bahwa: "Pendidikan Islam adalah pendidikan manusia seutuhnya; akal dan hatinya; rohani dan jasmaninya; akhlak dan ketrampilanya. Karena itu, pendidikan Islam menyiapkan manusia

\footnotetext{
${ }^{12}$ Al-Hasan, Al-furqon, Tafsir Al-Quran, (Surabaya: Tnp, 1956), 760

${ }^{13}$ Ibnu Katsir, Ibnu Kastir, (Singapur: tt) 432.

${ }^{14}$ Ahmad Anshori Al-Qurtubillah, (Kairo: Darus Sa'ab, tt) 510.
} 
untuk hidup, baik dalam keadaan damai maupun perang dan menyiapkanya untuk masyarakat dengan segala kebaikan dan kejahatanya, manis dan pahitnya". ${ }^{15}$

Hasan Langgulung merumuskan pendidikan Islam sebagai suatu "proses penyiapan generasi muda untuk mengisi peranan, memindahkan pengetahuan dan nilai-nilai Islam yang diselaraskan dengan fungsi manusia untuk beramal di dunia dan memetik hasilnya di akhirat". ${ }^{16}$

Menurut Syah Muhammad A. Naquib Al-Attas, Pendidikan Islam ialah usaha yang dilakukan pendidik terhadap anak didik untuk pengenalan dan pengakuan tempat-tempat yang benar dari segala sesuatu di dalam tatanan penciptaan. Sehingga, membimbing ke arah pengenalan dan pengakuan akan tempat Tuhan yang tepat di dalam tatanan wujud dan kepribadian. ${ }^{17}$

Muhammad Naqib Al-Attas dalam bukunya, Konsep Pendidikan Islam, dengan gigih mempertahankan penggunaan ta' dib $^{18}$ untuk konsep pendidikan Islam, bukan tarbiyah, dengan alasan bahwa dalam istilah ta'dib, mencakup wawasan ilmu dan amal yang merupakan esensi pendidikan Islam.

Dalam pandangan Al-Attas pendidikan Islam harus terlebih dahulu diberikan kepada manusia sebagi peserta didik, pendidikan tersebut berupa pengetahuan tentang manusia disusul dengan pengetahuan-pengetahuan lainnya. Dengan demikian dia akan tahu jati dirinya dengan benar, tahu "dari mana dia,

${ }^{15}$ Yusuf Al-Qardhawi, Pendidikan Islam dan Madrasah Hasan Al-Banna, terj. Bustami A. Gani dan Zainal Abidin Ahmad (Jakarta: Bulan Bintang, 1980),157.

16 Hasan Langgulung, Beberapa pemikiran tentang pendidikan Islam (Bandung: AlMa'arif, 1980), 94

${ }^{17}$ Hamdani Ihsan dan Fuad Hasan, Filsafat Pendidikan Islam (Bandung: Pustaka Setia, 1998), 16

${ }^{18}$ Kembali kepada definisi pendidikan Islam yang menurut Al-Attas diperuntutukan untuk manusia saja. menurutnya pendidikan Islam dimasukkan dalam At-ta'dib, karena istilah ini paling tepat digunakan untuk menggambarkan pengertian pendidikan itu, sementara istilah tarbiyah terlalu luas karena pendidikan dalam istilah ini mancakup juga pendidikan kepada hewan. Menurut Al-Attas Adabun berarti pengenalan dan pengakuan tentang hakikat bahwa pengetahuan dan wujud bersifat teratur secara hierarkis sesuai dengan beberapa tingkat dan tingkatan derajat mereka dan tentang tempat seseorang yang tepat dalam hubungannya dengan hakikat itu serta dengan kepastian dan potensi jasmaniah, intelektual, maupun rohaniah seseorang.ari pengertian Al-Attas tersebut dibutuhkan pemahaman yang mendalam, arti dari pengertian itu adalah, "pengenalan" adalah menemukan tempat yang tepat sehubungan dengan apa yang dikenali, sedangkan "pengakuan" merupakan tindakan yang bertalian dengan pengenalan tadi. Pengenalan tanpa pengakuan adalah kecongkakan, dan pengakuan tanpa pengenalan adalah kejahilan belaka. Dengan kata lain ilmu dengan amal haruslah seiring. Ilmu tanpa amal maupun amal tanpa ilmu adalah kesia-siaan. 
sedang dimana dia, dan mau kemana dia kelak". Jika ia tahu jati dirinya, maka ia akan selalu ingat dan sadar serta mampu dalam memposisikan dirinya, baik terhadap sesama makhluk, dan yang terlebih lagi kepada Allah SWT. Ketiga realita yaitu, manusia, alam, dan Tuhan diakui keberadaannya, dengan Tuhan sebagai sumber dari segalanya (alam dan manusia). Tuhan dapat dipahami sebagaimana dinformasikan dalam Al-Quran sebagi Rabb al-Alamin, dan Rabb alNass. Amrullah Ahmad menilai bahwa dalam definisi pendidikan Al- Attas mengandung proses pengajaran seseorang dalam tatanan kosmis dan sosial yang akan mengantarkannya untuk menemukan fungsinya sebagi kholifah.

Terlepas dari seberapa jauh ketepatan argumen Naquib Al-Attas mengenai penggunaan istilah ta'dib bagi pendidikan Islam, dalam pembahasan ini tidak ingin diperdebatkan karena sesungguhnya ketiga istilah tersebut (tarbiyah, ta'lim, dan ta'dib) merupakan satu kesatuan yang saling terkait. Artinya bila pendidikan dinisbatkan kepada ta'dib ia harus melalui pengajaran (ta'lim) sehingga dengannya diperoleh ilmu. Agar ilmu dapat dipahami, dihayati, dan selanjutya diamalkan oleh peserta didik perlu bimbingan (tarbiyah).

Dalam konsep pendidikan Islam, tujuan pendidikan bukan untuk Tuhan tetapi semata-mata untuk memelihara eksistensi manusia sebagai makhluk terbaik. Itulah sebabnya manusia sebagai pendidik juga harus mengerti kebutuhan peserta didik sesuai dengan fitrahnya karena kebutuhan manusia inheren dalam fitrah tersebut. Ia mendidik untuk memelihara dan mengembangkan fitrah itu. Berkenaan dengan masalah ini Abdurrahman an-Nahlawi menjabarkan konsep attarbiyah dalam empat unsur: Pertama, Memelihara pertumbuhan fitrah manusia. Kedua, mengarahkan perkembangan fitrah manusia menuju kesempurnaannya. Ketiga, mengembangkan potensi insani (sumber daya manusia) untuk mencapai kualitas tertentu. Dan Keempat, melaksanakan usaha-usaha tersebut secara bertahap.sesuai dengan irama perkembangan anak. ${ }^{19}$

19 Implikasi penggunaan istilah dan konsep tarbiyah dalam pendidikan Islam ialah: pertama, pendidikan bersifat humanis-teosentris artinya berorientasi pada fitrah dan kebutuhan dasar manusia, yang diarahkan sesuai dengan sunnah (scenario) Tuhan "pencipta". Kedua, pendidikan bernilai ibadah karena tugas pendidikan bagian dari tugas kekhalifahannya, sedangkan pendidik yang hakiki adalah Allah "Rabbul'alamin". Ketiga, Tanggungjawab pendidikan tidak 
Jadi pendidikan Islam adalah sistem pendidikan yang dapat memberikan kemampuan seseorang untuk memimpin kehidupanya sesuai dengan cita-cita Islam, karena nilai-nilai Islam telah menjiwai dan mewarnai corak kepribadianya. Dari pengertian-pengertian diatas, dapatlah kita mengambil benang merah pengertian pendidikan Islam. Pendidikan Islam adalah pendidikan manusia seutuhnya yang dilakukan oleh seorang dewasa kepada anak didik untuk mempersiapkan kehidupan yang lebih baik. Dalam prakteknya, pendidikan Islam bukan hanya pemindahan pengetahuan kepada anak didik, namun perlu diintegrasikan antara tarbiyah, ta'lim dan ta'dib, sehingga dapatlah seseorang yang telah mendapatkan pendidikan Islam memiliki kepribadian muslim yang mengimplementasikan syari'at Islam dalam kehidupan sehari-hari, serta hidup bahagia di dunia dan akhirat.

Sedangkan strategi pengembangan pendidikan Islam mengandung pengertian rangkaian perilaku pendidik yang tersusun secara terencana dan sistematis untuk menginformasikan, mentransformasikan, dan menginternalisasikan nilai-nilai Islami agar dapat membentuk kepribadian muslim seutuhnya. Strategi pengembangan dalam pendidikan islam ini dapat dilakukan dengan cara: Pertama, mengusahakan nilai-nilai Islami dalam pendidikan Islam menjadi ketentuan standar atau baku bsgi pengembangan moral atau ahlak masyarakat yang selalu mengalami perubahan. Kedua, mengusahakan peran pendidikan Islam yang mengembangkan moral atau ahlak peserta didik sebagai dasar pertimbangan dan pengendali tingkah lakunya dalam menghadapi norma sekuler. Ketiga, mengusahakan norma Islami yang mampu menjadi pengendali kehidupan pribadi dalam menghadapi goncangan hidup dalam menghadapi era globalisasi ini sehingga para peserta didik mampu menjadi sumber daya manusia yang berkualitas. Keempat, mengusahakan nilai-nilai Islami yang dapat menjadi pengikat hidup bersama dalam rangka mewujudkan persatuan dan kesatuan umat Islam yang kokoh dengan tetap memperhatikan lingkup kepentingan bangsa. Kelima, mengusahakan hilangnya sifat ambifalensi pendidikan Islam agar tidak 
timbul pandangan yang dikotomis, yakni pandangan yang memisahkan secara tajam antara tujuan ilmu dan agama, sementara ilmu merupakan alat utama dalam menjangkau kebenaran yang menjadi tujuan agama.

Beberapa pendekatan dapat ditawarkan dalam strategi pengembangan pendidikan Islam ini, antara lain:

6. Pendekatan Filsafat Islam

Pendekatan ini menekankan pada keyakinan bahwa Islam adalah wahyu Allah, sehingga kita tidak perlu meragukan dan yakin bahwa segala isi wahyu tersebut mengandung kebenaran yang mutlak.

7. Pendekastan Sosiologis

Yaitu cara pandang yang menekankan pada serangkaian norma-norma hidup bermasyarakat yang diyakini sebagai sesuatu yang baik. Norma-norma itu dijadikan pedoman pembinaan perilaku hidup sehari-hari dalam masyarakat dan dapat membedakan sec ara tegas mana yang harus disingkirkan dan mana yang tidak, untuk menciptakan kehidupan bersama. Pendekatan ini menekankan bahwa pendidikan Islam adalah sebagai pengendali awtau pengarah perilaku manusia terhadap tuntutan peubahan social, di mana iman dan takwa menjadi landasan penerrapan atau pengamalannya dlam masyarakat..

8. Pendekatan Pedagogis.

Yaitu pendekatan yang menekankan terbentuknya perilaku yang baik bagi setiap muslim dalam melaksanakan perilaku hidup sehari-hari sebagai landasan hidupnya di akherat. Oleh sebab itu dalam kegiatan pendidikan Islam perlu menggunakan pendekatan perilaku sebagai cara pandang pendidikan Islam yang memberikan kejelasan tentang rangkaian kegitan yang dapat mengembangkan perilaku manusia.

\section{Pendekatan Sistem}

Yaitu cara pandang Pendidikan Islam berdasarkan system dapat digambarkan sebagai proses belajr-mengajar yang dipengaruhi masyarakat Islam untuk menghasilkan lulusan yang mampu berperan dalam hidupnya untuk mempengaruhi dan mengembangkan kehidupan orang islam dalam lingkup kehidupan masyarakat yanglebih luas. Sebagai suatu system maka pendidikan 
Islam tidak dapat berdiri sendiri sama sekali terlepas dri lingkungannya, bangsanya, budayanya, atau pengaeruh bermacam-macam aspek kehidupan.

\section{Konsep Fitrah Dalam Pendidikan Islam}

Banyak yang mengartikan bahwa bayi yang lahir itu fitrah; artinya suci. Jiwa anak tersebut cenderung kepada agama tauhid. Ketika terjadi penyimpangan dalam perkembangan anak itu untuk tidak lagi cenderung kepada agama tauhid, para ulama berargumentasi bahwa hal itu disebabkan oleh beberapa hal, antara lain:

1. Pengaruh adaptasi dan pergaulan.

2. Pengaruh lingkungan.

3. Pengaruh hawa nafsu dan kekuasaan

4. Adanya pendidikan

5. Guru yang mengajarnya

6. Perbuatan atau usaha kedua orang tuanya.

Sabda Rasulullah: "Manusia dilahirkan dalam keadaan suci atau fitrah, hanya ibu bapaknya yang menyebabkan ia mejadi Yahudi, nasrani atau majusi."

Hasan Langgulung memaknai hadist di atas bahwa potensi dasar yang baik. Sebab pengertian menjadi Yahudi, Nasrani, Majusi itu adalah bermakna menyesatkan. Maksudnya ibu bapak itulah yang merusak dan menyesatkan fitrah yang asalnya suci dan sepatutunya kearah yang baik. ${ }^{20}$

Untuk pengertian suci, bersih, bukan berarti bahwa fitrah disini sama dengan tabularasanya John Locke (1632-1704). Meskipun fitrah punya arti suci bersih, tetapi fitrah tidak kosong. Fitrah berisi daya-daya yang wujud dan perkembangannya tergantung pada usaha manusia sendiri. ${ }^{21}$ Oleh karena itu, fitrah harus dikembalikan dalam bentuk-bentuk keahlian, laksana emas atau minyak yang terpendam dalam perut bumi, tidak ada gunanya kalau tidak digali dan diolah untuk kegunaan manusia. Disinilah tugas utama pendidikan.

\footnotetext{
${ }^{20}$ Hasan Langgulung, Peradaban dan pendidikan Islam...215.

${ }^{21}$ Mastuhu, Dinamika system Pendidikan Pesantren: Suatu Kajian tentang Unsur dan Nilai Sistem Pendidikan Pesantren, (Jakarta: INIS, 1994), 16.
} 
Sedangkan pendidikan sangat dipengaruhi oleh factor pembawaan dan lingkungan. Namun ada perbedaan esensial antara pendidikan Islam dengan pendidikan umum. Pendidikan Islam berangkat dari filsafat pendidikan theocentric, sedangkan pendidikan umum berangkat dari filsafat antropocentric.

Theocentris memandang bahwa semua yang ada diciptakan oleh Tuhan berjalan menurut hukumnya. Filsafat ini memandang bahwa manusia dilahirkan sesuai dengan fitrahnya dan perkembangan selanjutnya tergantung pada lingkungan dan pendidikan yang diperolehnya. Sedangkan seorang pendidik dan guru hanya bersifat membantu, serta memberikan penjelasan-penjelasan sesuai dengan tahap perkembangan dan pemikiran dan akhirnya pelajar sendirilah yang belajar. Sedangkan filsafat antropocentrc, lebih mendasarkan ajarannya pada hasil pemikiran manusia dan berorientasi pada kemampuan manusia dalam hidup keduniawian. $^{22}$

Sehubungan dengan ini, maka persamaan dan perbedaan pendidikan Islam dan aliran empirisme ialah: pertama, keduanya sepakat bahwa anak yang baru lahir adalah bersih dan suci, ibarat kertas putih yang siap ditulis oleh pendidik. Kedua, karena adanya perbedaan konsep antara konsep fitrah dan teori tabularasa, maka peranan para pendidik dalam konsep pendidikan Islam lebih terbatas dibandingkan dengan peranan pendidik dalam aliran empirisisme, dalam membentuk dan mengembangkan kepribadian anak didik tersebut.

Persamaan dan perbedaan pendididkan Islam dengan aliran nativisme: pertama, keduanya mengakui pentingnya faktor pembawaan, sehingga anak didik berperan besar dalam membentuk dan mengembangkan kepribadiaannya. Fungsi pendidik dalam hal ini lebih banyak sebagai fasilitator. Kedua,dalam pendidikan Islam, karena adanya nilai agama yang memiliki kebenaran mutlak, maka pendidik bukan hanya sekadar pembantu tetapi ia bertanggung jawab akan terbentuknya kepribadian muslim pada anak didik.

Persamaan dan perbedaan pendidikan Islam dengan konvergensi: pertama, keduanya mengakui pentingnya factor endogen dan eksogen dalam membentuk dan mengembangkan kepribadian anak didik. Kedua, perbedaannya, dalam Islam

\footnotetext{
${ }^{22}$ Ibid., 16.
} 
ke mana kepribadian itu harus dibentuk dan dikembangkan sudah jelas, yaitu ma'rifatullah dan bertakwa kepada-Nya. Sedang dalam pendidikan yang antroposentrik pembentukan dan pengembangan kepribadian diarahkan untuk mencapai kedewasaan dan kesejahteraan hidup di dunia.

Oleh karena itu fitrah manusia dengan segala potensinya sebagaimana dipaparkan diatas merupakan "conditional statement (citra bersyarat), dan aktualisasinya menuntut upaya manusia sendiri.

Berbeda dengan paham materialisme yang meyakini bahwa manusia mati berarti hilangnya eksistensi manusia secara total. Dalam Islam, fitrah manusia itu setelah mati akan kembali kepada Allah. Upaya pengembangan fitrah manusia yang meliputi spiritual, intelektual, dan keterampilan yang dapat dimanfaatkan untuk kemajuan dan kesejahteraan hidup hanyalah dalam rangka mengabdi kepada-Nya. Oleh karena itu fitrah haruslah dikembangkan dan dilestarikan.

\section{Penutup}

Dalam pendidikan Islam tetap berpijak pada kekuatan hidayah Allah yang menentukan nilai akhir. Dalam pendidikan Islam hidayah Allah menjadi sumber spiritual yang menjadi penentu keberhasilan akhir dari proses ikhtiariyah manusia dalam pendidikan. Sesuai dengan kajian ini, maka agar pendidikan berhasil dan memperoleh hidayah Allah, manusia harus menghadapkan wajahnya kepada Islam secara kaffah.

Allah menunjukkan dua jalan, jalan yang benar dan jalan yang sesat, dan manusia diberi kebebasan untuk memilih dua jalan tersebut. ${ }^{23}$ Dari dua jalan adakalanya manusia bersyukur, adakalanya kufur yaitu memilih jalan yang sesat. ${ }^{24}$ Ketentuan Allah menun jukkan pada dua kecenderungan, yaitu kecenderungan nafsu untuk menjadi kafir yang ingkar terhadap Tuhannya dan kecenderungan yang bersikap bertakwa yang mentaati perintah-Nya. ${ }^{25}$ Ayat ini dapat dijadikan sumber pandangan bahwa usaha mempengaruhi jiwa manusia melalui pendidikan

${ }^{23}$ Q.S. al-Balad: 10

${ }^{24}$ Q.S. al-Insan: 3

${ }^{25}$ Q.S.as-Syamsu: 7-10 
46 - 46 | Tafhim Al-'Ilmi, September 2019

dapat berperan positif untuk mengarahkan perkembangan kepada jalan kebenaran yaitu Islam. Dengan tanpa melalui usaha pendidikan, manusia akan terjerumus ke jalan yang sesat, dengan kata lain mengingkari fitrahnya sendiri.

Maka pantas jika pendidikan Islam itu mendidik manusia dalam mendalami agama Islam, mengetahui Allah, dan dalam mengetahui dirinya. Dengan demikian fitrah dalam pendidikan Islam dapat diartikan sebagai perintah perintah mempelajari agama Islam, perintah mengenal Allah, dan perintah mengenal dirinya, yang dijalani oleh manusia melalui proses pendidikan Islam.

\section{Daftar Pustaka}

Hasan Langgulung, Pendidikan dan Peradaban Islam, Jakarta: Pustaka Al Husna, 1985.

Luis Ma'luf, Al Munjid,Beirut: tt.

M. Quraish Shihab, Wawasan Alqur'an, Bandung: Mizan, 1996.

Mastuhu, Dinamika system Pendidikan Pesantren: Suatu Kajian tentang Unsur dan Nilai Sistem Pendidikan Pesantren,Jakarta: INIS, 1994.

Muis Sad Iman, Pendidikan Partisipatif: Menimbang Konsep Fitrah dan progrsivisme John Dewe, Yogyakarta: Safiria Insania Press, 2004.

Ibnu Katsir, Ibnu Kastir, Singapur: tt.

WJS Poerwodarminto, Kamus Umum Bahasa Indonesia, Jakarta: Balai Pustaka, 1952

Yusuf Al-Qardhawi, Pendidikan Islam dan Madrasah Hasan Al-Banna, terj. Bustami. 